\title{
TO STUDY THE CAUSATIVE ORGANISM OF CORNEAL ULCER IN A TERTIARY CARE HOSPITAL
}

\author{
Keisham Sorojini Devi' ${ }^{1}$ Lhingkhohat Haokip², Supriya Laifangbam³ ${ }^{3}$ Rajkumari Bhabanisana Devi ${ }^{4}$
}

${ }^{1}$ Assistant Professor, Department of Ophthalmology, Jawaharlal Nehru Institute of Medical Sciences, Porompat, Imphal, Manipur. ${ }^{2}$ Assistant Professor, Department of Ophthalmology, Jawaharlal Nehru Institute of Medical Sciences, Porompat, Imphal, Manipur. ${ }^{3}$ Associate Professor, Department of Microbiology, Jawaharlal Nehru Institute of Medical Sciences, Porompat, Imphal, Manipur. ${ }^{4}$ Former Professor and HOD, Department of Ophthalmology, Jawaharlal Nehru Institute of Medical Sciences, Porompat, Imphal, Manipur.

\section{ABSTRACT}

\section{BACKGROUND}

Early microbiological examination and treatment of corneal ulcer will prevent further permanent ocular damage in the form of loss of vision and other abnormalities.

Aim is to study the common predisposing factors, isolate and identify the bacteria and fungi responsible for the corneal ulcer, and the drug sensitivity pattern of isolated bacteria to the commonly used antibiotics in a tertiary care hospital.

\section{MATERIALS AND METHODS}

In a cross-sectional study, fifty patients of established corneal ulcer were examined, microbiological study carried out and common predisposing factors studied during the period of November 2013 to October 2015 in a government run tertiary care ophthalmic teaching hospital.

\section{RESULTS}

$66 \%$ cases were found culture positive of which $40 \%$ were bacteria, $16 \%$ were fungal and $10 \%$ were mixed infection. Staphylococcus aureus was the predominant bacterial isolate and Aspergillus species was the commonest fungal isolate. Males and females were equally affected. The highest incidence of bacterial keratitis and mycotic keratitis were $68 \%(17 / 25)$ and $38.6 \%$ (5/13) respectively in the age group of 41 - 50 years. Farmers were commonly affected due to trauma during the harvesting season of December to February. Six cases (46\%) of fungus positive cases were associated with trauma due to paddy leaf. Most of the organisms were sensitive to moxifloxacin, ofloxacin, amikacin and vancomycin.

\section{CONCLUSION}

Corneal ulcer was commonly found in the adults and more so among the low socio-economic group and in the rural areas where cultivators were more prone to develop corneal ulcer due to trauma during the harvesting season. Staphylococcus aureus and Aspergillus were the commonest pathogenic organisms. Fluoroquinolone appeared to be the therapy of choice for bacterial keratitis with moxifloxacin as the most sensitive antibiotic.

\section{KEYWORDS}

Corneal Ulcer, Bacterial Ulcer, Mycotic Ulcer, Swab, Staining, Culture.

HOW TO CITE THIS ARTICLE: Devi KS, Haokip L, Laifangbam S, et al. To study the causative organism of corneal ulcer in a tertiary care hospital. J. Evolution Med. Dent. Sci. 2017;6(1):42-45, DOI: 10.14260/Jemds/2017/12

\begin{abstract}
BACKGROUND
Infectious corneal ulcer is a major cause of ocular morbidity and blindness throughout the world. Corneal Ulcer is the clinical condition characterised by suppurative inflammation of cornea with loss of continuity of epithelium. The disease has become an important health problem as it causes significant and often an irreversible damage to cornea resulting in decreased vision and even blindness.
\end{abstract}

Financial or Other, Competing Interest: None.

Submission 23-11-2016, Peer Review 21-12-2016,

Acceptance 27-12-2016, Published 02-01-2017.

Corresponding Author:

Dr. Keisham Sorojini Devi,

Assistant Professor,

Department of Ophthalmology,

Jawaharlal Nehru Institute of Medical Sciences,

Porompat, Imphal-795005,

Manipur.

E-mail: drsorojini@yahoo.com

DOI: $10.14260 /$ jemds $/ 2017 / 12$
Principal agents of bacterial keratitis are Staphylococcus, Pseudomonas, Streptococcus, Escherichia coli, Klebsiella species, and mycotic keratitic agents are Aspergillus, Fusarium and Candida. Infective corneal ulcer presents with acutely painful, intensely injected eye, watering foreign body sensation, photophobia, redness and decreased vision. Mycotic corneal ulcer presents with mild symptoms, progresses slowly with dry and feathery margin surrounded by yellow line of demarcation, an immune ring, satellite lesions and hypopyon. The spectrum of bacterial and fungal agents responsible for corneal ulcer is wide, showing variation from one country to another and from season to season and in different geographic regions according to climate and occupational risk factors. Clinical features alone are not sufficient to diagnose corneal ulcer until and unless proper microbiological study is carried out.

\section{Aim}

To study the common predisposing factors, isolate and identify the bacteria and fungi responsible for the corneal ulcer, and the drug sensitivity pattern of isolated bacteria to the commonly used antibiotics in a tertiary care hospital. 


\section{MATERIALS AND METHODS}

After the Institutional Ethics Committee's approval and written informed consent, fifty clinically established patients of corneal ulcer of different age and sex who have not applied any medication for 3 to 4 days prior to attending at tertiary care ophthalmic teaching hospital during the period of November 2013 to October 2015 were included in this crosssectional study. However, unwilling patients for corneal scraping, congenital malformation of the cornea, those with chemical injury, patients with suspected or confirmed viral keratitis, healing ulcers, perforated corneal ulcer, Mooren's ulcer, marginal keratitis, interstitial keratitis, atheromatous ulcer, neurotrophic keratitis, and any ulcer associated with systemic or autoimmune diseases were excluded from this study. Lacrimal sac syringing, IOP measurement, routine blood examination and blood sugar testing were done in all the cases.

Detailed clinical history and examination were done under slit lamp after instillation of $2 \%$ fluorescein dye. Materials for microbiological studies were collected with sterile cotton-swabs after instillation of $4 \%$ lignocaine hydrochloride into the affected eye and after gentle scraping with blunt edge of No. 15 BP knife from the margins as well as from the ulcer base.

The corneal swabs from the ulcer were examined for i) Gram's stain ii) $10 \% \mathrm{KOH}$ mount iii) bacterial culture and iv) fungal culture. The Gram stained smear was examined for bacteria and yeasts. The $\mathrm{KOH}$ preparation was examined for the presence of fungal filaments. For bacterial culture, the scraped material was incubated in blood agar, MacConkey's agar media and then incubated at $37^{\circ} \mathrm{C}$ for $24-48$ hours. For fungal culture, the swab was inoculated into Sabouraud dextrose agar media which was incubated at room temperature, and at $37{ }^{\circ} \mathrm{C}$ for 3 weeks. Bacterial isolates were identified on the basis of colony characteristics, morphology and biochemical test ${ }^{1}$ and subjected to antibiotic sensitivity test. Fungi were identified by studying the morphological character and other relevant biochemical test. ${ }^{2}$

\section{RESULTS}

In the present study, fifty patients of established corneal ulcer were enrolled. The highest incidence of bacterial keratitis and mycotic keratitis were $68 \%(17 / 25)$ and $38.6 \%(5 / 13)$ respectively in the age group of 41 - 50 years. Both sexes were equally affected. The most affected population was found in farmers (40\%); closely followed by house wives $(22 \%)$ and labourer (10\%). A biannual rise of corneal ulcer cases was reported during the month of December to February i.e., December (16\%), November (14\%) and February $(14 \%)$ and in the month of July to August $(12 \%$ each). The people from rural areas with lower socioeconomic back ground were mostly affected.

$32 \%$ of the cases gave history of injury with paddy leaf, followed by bamboo stick (8\%), straw (6\%) and vegetable matters. Corneal ulcer without history of trauma was $26 \%$ and $80 \%$ of the cases did not have any associated disease.

Out of the 50 corneal ulcer cases, aetiologic agents were isolated from 33 cases (66\%) of which bacterial agents accounted for $20(40 \%)$ and fungal agents for $8(16 \%)$ and $5(10 \%)$ for mixed infections. Among the bacterial isolates, Staphylococcus aureus was the commonest agent 7 (23.33\%), followed by Streptococcus pneumonia 6 (20\%),
Pseudomonas species 5 (16.66\%) and Escherichia coli 4 (13.33\%) (Table 1). Among the fungal isolates, Aspergillus fumigatus 5 (38.46\%) followed by Mucormycosis 2 (15.38\%) and Cladosporium $2(15.38 \%)$ were the common organisms (Table 2).

Eighty $(80 \%)$ of the cases did not have any associated condition of corneal ulcer. In the rest $20 \%$, there was one case $(2 \%)$ having dacryocystitis with block nasolacrimal duct on syringing and another case $(2 \%)$ with high blood sugar. Most common association was found with gross debility $10 \%$, followed by entropion and trichiasis $4 \%$ and glaucoma $2 \%$ (Table 3). Most of the organisms were sensitive to moxifloxacin, ofloxacin, amikacin and vancomycin.

\begin{tabular}{|c|c|c|c|}
\hline Type of Bacteria & No. of Cases & Percentage & p-value \\
\hline Staph. aureus & 7 & 23.33 & $<0.001$ \\
\hline Staph. epidermidis & 3 & 10.00 & $<0.0001$ \\
\hline Strep. pneumoniae & 6 & 20.00 & $<0.0001$ \\
\hline Pseudomonas & 5 & 16.66 & $<0.0001$ \\
\hline Klebsiella Species & 1 & 3.33 & $<0.0001$ \\
\hline Escherichia coli & 4 & 13.33 & $<0.0001$ \\
\hline Acinetobacter & 1 & 3.33 & $<0.0001$ \\
\hline Non-lactose fermenter & 2 & 6.66 & $<0.0001$ \\
\hline Diphtheroids & 1 & 3.33 & $<0.0001$ \\
\hline Total & 30 & 100 & \\
\hline 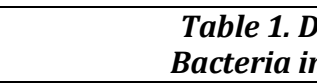 & & $\begin{array}{l}\text { ed } \\
t h\end{array}$ & \\
\hline
\end{tabular}

$\mathrm{X} 2=9.187, \mathrm{p}>0.05$

\begin{tabular}{|c|c|c|c|}
\hline Type of Fungi & No. of Case & Percentage & p-value \\
\hline Asp. Fumigates & 5 & 38.46 & $<0.001$ \\
\hline Candida species & 1 & 7.69 & $<0.0001$ \\
\hline Mucor species & 2 & 15.38 & $<0.0001$ \\
\hline Cladosporium & 2 & 15.38 & $<0.0001$ \\
\hline Chaetomium & 1 & 7.69 & $<0.0001$ \\
\hline Pseudallescheria boydii & 1 & 7.69 & $<0.0001$ \\
\hline Acremonium & 1 & 7.69 & $<0.0001$ \\
\hline Total & 13 & 100 & \\
\hline \multicolumn{4}{|c|}{$\begin{array}{l}\text { Table 2. Distribution of Isolated } \\
\text { Fungi including mixed Growth }\end{array}$} \\
\hline
\end{tabular}

$\mathrm{X}^{2}=3.311, \mathrm{p}>0.05$

\begin{tabular}{|c|c|c|c|}
\hline Disease & $\begin{array}{l}\text { No. of } \\
\text { Cases }\end{array}$ & Incidence & p-value \\
\hline Diabetes & 1 & 2 & $<0.0001$ \\
\hline Glaucoma & 1 & 2 & $<0.0001$ \\
\hline Dacryocystitis & 1 & 2 & $<0.0001$ \\
\hline $\begin{array}{c}\text { Entropion \& } \\
\text { trichiasis }\end{array}$ & 2 & 4 & $<0.0001$ \\
\hline Gross debility & 5 & 10 & $<0.0001$ \\
\hline $\begin{array}{c}\text { No associated } \\
\text { disease }\end{array}$ & 40 & 80 & $<0.0001$ \\
\hline Total & 50 & 100 & \\
\hline
\end{tabular}

$\mathrm{X}^{2}=81.04, \mathrm{p}<0.0001$.

\section{DISCUSSION}

In this study, corneal ulcer has no definite predilection for any sex. The highest incidence of bacterial keratitis and 
mycotic keratitis were $68 \%(17 / 25)$ and $38.6 \%(5 / 13)$ respectively in the age group of 41 - 50 years. This could be because of the active exposure of most of the patients of this age group, compared to the young and the old aged, to frequent ocular trauma and infection in their day-to-day life. Similar observations were made by Dutta LC et al,3 Siva RP et $\mathrm{al}^{4}$ and Soja MR. ${ }^{5}$ The corneal ulcer in the older age group was found to be related to the debilitated condition and lack of body resistance.6,4 Subbanayya et $\mathrm{al}^{7}$ found corneal ulcer cases most common in between 10-39 years of age. However, Amatya $\mathrm{R}$ et $\mathrm{al}^{8}$ and Katara $\mathrm{RS}$ et $\mathrm{al}^{9}$ reported that the corneal ulcer was most pronounced in patients who were between the age of 21-30 years and 20-70 years respectively. The equal distribution of the incidence in both males and females was because of equal sharing to manual and field works in our place. This finding is in agreement with a study.10 However, males are more prone to mycotic corneal ulcer than females because of the fact that males are more likely to sustain injuries due to their nature of work in outdoors. Same findings were reported by Dutta LC et al, ${ }^{3}$ Sharma SL, 11 Jayahar $\mathrm{BM}^{12}$ and Katara RS et al. ${ }^{9} \mathrm{~A}$ higher incidence of fungal keratitis among females than males was also noted in another study. ${ }^{7}$

In our study, the corneal ulcer commonly occurred during the winter and rainy season with fungal keratitis prevailing more in the winter. Comarella JD et al ${ }^{13}$ also reported fungal ulcers occurred predominantly in the months of June and December. However, Subbannayya $\mathrm{K}$ et $\mathrm{al}^{7}$ found no seasonal difference in the incidence of fungal corneal ulcer. In the present study, most of the patients were cultivators and ocular trauma was due to paddy leaf. This could be because the farmers were maximally exposed in the field works during these months for harvesting and plantation. This finding is in agreement with the study of Katara RS et al. ${ }^{9}$ Our findings were comparable to those found by other workers. ${ }^{14,15,3,16,6,17}$ The present study further revealed a definite relation of mycotic keratitis rather than bacterial to injury sustained while working in the field showing similar observations of other authors. $11,17,8,9,18$

In the present study of 50 patients, $66 \%$ cases showed culture positive; $40 \%$ are bacterial, $16 \%$ are fungal and $10 \%$ are mixed infection which were comparable to that of Comarella JD et al, ${ }^{13}$ Rocha GAN. ${ }^{19}$ However, Amatya R et al, 8 Katara RS et al, ${ }^{9}$ Akter L et al,18 Rautaraya B et al20 and Bharathi $\mathrm{MJ}$ et $\mathrm{al}^{21}$ reported fungi were the predominant agents for corneal ulcer. The low incidence of positive cases in our study may be due to the prior use of local medication before attending the hospital. Among the isolated bacterial and fungal organisms, Staphylococcus aureus and Aspergillus species were the commonest organisms which was almost same as those reported by various authors. ${ }^{44,22,7,8,18}$ However, Katara RS et al $^{9}$ found Pseudomonas aeruginosa and Aspergillus species were the most commonly isolated organisms whereas Sood NN, ${ }^{17}$ Poria VC ${ }^{23}$ and Comarella JD et $\mathrm{al}^{13}$ reported Pseudomonas aeruginosa and Fusarium species were the most frequently isolated organisms. In our study, Streptococcal species was the second commonest bacterial isolate for corneal ulcer12,16 whereas Mucor and Cladosporium species were also other fungal isolate from corneal ulcer. These results showed that there are wide variations regarding the aetiological agents of corneal ulcer from one country to another country.
In our study, $4 \%$ of corneal ulcers were associated with entropion and trichiasis, 2\% each with diabetes, glaucoma and dacryocystitis. Siva Reddy $\mathrm{P}$ et $\mathrm{al}^{4}$ also reported mycotic ulcer in diabetic patients. Diabetes lowers body resistance and so the fungus takes the upper hand.

The overall isolation of microbial agents from corneal ulcer cases was almost similar to those from the normal conjunctival sac and most of the organisms were sensitive to moxifloxacin.

\section{CONCLUSION}

The study showed that corneal ulcer was commonly found in the active adults and more so among the low socioeconomic group and in the rural areas. Cultivators were more prone to develop corneal ulcer because of the commonest predisposing factor, trauma during the harvesting season. Both sexes were equally affected because of equal sharing in the manual and outdoor works. The commonest pathogenic organisms among the isolated bacterial and fungal organisms were Staphylococcus aureus and Aspergillus respectively. Fluoroquinolone appeared to be the therapy of choice for bacterial keratitis with moxifloxacin as the most sensitive antibiotic.

\section{REFERENCES}

[1] Barrow GI, Feltham RKA. Cowan and Steel's manual for the identification of medical bacteria. Principles of isolation, bacterial characters and characterization, theory and practice of bacterial identification. $3^{\text {rd }}$ edn. New York: Cambridge University Press, Cambridge 1993:15-49.

[2] Rippon JW. Culture Methods, media, stains and serologic procedures, medical mycology, the pathogenic fungi and pathogenic actinomycetes. $2^{\text {nd }}$ edn. Philadelphia: WB Saunders Company 1982:772 95.

[3] Dutta LC, Dulal D, Mahanty P, et al. Study of fungus keratitis. Indian Journal of Ophthalmology 1981;29(4):407-9.

[4] Reddy PS, Satyendran OM, Satapathy M, et al. Mycotic keratitis. Indian Journal of Ophthalmology 1972;20(3):101-8.

[5] Soja MR, Manaviat M. Epidemiology and outcome of corneal ulcer in Yazd Shahid Sadoughi hospital. Act Medica Iranica 2004;42(2):136-41.

[6] Arora S, Tyagi SC. Fungal flora of conjunctival sac in health and disease. Indian Journal of Ophthalmology 1976;24(1):15-8.

[7] Subbannayya K, Mamatha B, Jyothirlatha, et al. Mycotic keratitis. A study in coastal Karnataka. Indian Journal of Ophthalmology 1992;40(1):31-3.

[8] Amatya R, Shrestha S, Khanal B, et al. Etiological agents of corneal ulcer: five year prospective study in eastern Nepal. Nepal Medical College Journal 2012;14(3):219-22.

[9] Katara SR, Patel DN, Sinha M. A clinical microbiological study of corneal ulcer patients at western Gujarat, India. Acta Medica Iranica 2013;51(6):399-403.

[10] Upadhyay MP, Karmacharya PC, Koirala S, et al. Epidemiologic characteristic, predisposing factors and etiologic diagnosis of corneal ulceration in Nepal. American Journal Ophthalmology 1991;111(1):92-9. 
[11] Sharma SL. Keratomycosis in corneal sepsis. Indian Journal of Ophthalmology 1981;29(4):443-5.

[12] Bharathi MJ, Ramakrisnan R, Vasu S, et al. In - vitro efficacy of antibacterial against bacterial isolates from corneal ulcer. Indian Journal of Ophthalmology 2002;50(2):109-14.

[13] Comarella JD, Saraiva PGC, Saraiva FP. Corneal ulcer: a retrospective study of a cases seen at hospital das Clinicas, Federal University of Espirito Santo. Rev Bras Oftalmol 2015;74(2):77-80.

[14] Behari KV, Srivastava D. Various factors in aetiopathogenesis of galloping corneal ulcer and their response to therapy. Indian Journal of Ophthalmology 1983;31(5):692-7.

[15] Chaddah MR, Agarwal DC. Treatment of Keratomycosis with amphotericin B. ointment. Indian Journal of Ophthalmology 1978;26(1):9-11.

[16] Panhalkar S, Thomas A, Alexander TA, et al. Bacterial and mycotic agents of corneal ulcer in Vellore. Indian Journal of Ophthalmology 1985;33(5):289-93.

[17] Sood NN, Ratharaj A, Balaraman G. Clinico - bacterial study of corneal ulcer. Orient Arch Ophth 1968;6:93108.
[18] Akter L, Salam MA, Hasan B, et al. Etiological agents of suppurative corneal ulcer: study of 56 cases. Bangladesh Journal of Medical Microbiol 2009;3(1):33-6.

[19] Rocha GAN, Silva RF, Lopes MF, et al. Principais patogenos e susceptibilidade in vitro antimicrobiana em ceratites bacterianas. Revisao de cinco anos 2005 a 2009. Arq Bras Oftalmol 2011;74(1):28-32.

[20] Rautaraya B, Sharma S, Kar S, et al. Diagnosis and treatment outcome of mycotic keratitis at a tertiary eye care center in eastern India. BMC Ophthalmol 2011;11:39.

[21] Bharathi MJ, Ramakrishnan R, Meenakshi R, et al. Microbial keratitis in South India: influence of risk factors, climate and geographical variation. Ophthalmic Epidemiol 2007;14(2):61-9.

[22] Panjarathinam R, Kollali VV, Dixit CV, et al. Bacterial and mycotic keratoconjunctivitis. Indian Journal of Ophthalmology 1979;27(3):29-32.

[23] Poria VC, Bharad VR, Dongre DS, et al. Study of Mycotic keratitis. Indian Journal of Ophthalmology 1985;33(4):229-31. 